\title{
HUMIDITY IN ANAESTHESIOLOGY: I. A MODIFIED DEW-POINT HYGROMETER
}

\author{
R. DÉRY, M.D., F.R.C.P.(C), J. Pelletuer, M.D., \\ A. JACQUES, M.D., F.R.C.P.(C), F.F.A.R.C.S., \\ M. Clavet, M.D., and J. J. Houde, M.D.*
}

THE NEED for a continuous or intermittent monitoring of water vapour during anaesthesia is of increasing importance. There is a strong concern among anaesthesiologists for close supervision of every component of the inhaled gas mixture, including its water vapour pressure. Moisture generators that can be incorporated in anaesthesia systems are now readily available and have recently been used in some hospitals. ${ }^{1}$ The ultimate decision to provide the anaesthetic machine with such devices results from the currently popular theory that anaesthetized patients are usually forced to breathe an atmosphere not dissimilar in moisture content to that of the Sahara Desert.

To date, the measurement of water loss from the respiratory tract of patients during anaesthesia has required the use of gravimetric devices with cryogenic or chemical absorbents, as described by Seeley ${ }^{2}$ and Burch. ${ }^{3}$ Dry-and-wet-bulb psychrometers have been used to measure the humidity and temperature of both inhaled and expired air in the corrugated tubings of the circle. Valuable data were thus gathered that could provide indirect information about the evolution of water in the bronchial tree, assuming that vaporization from the respiratory tract can be defined as the difference between inspired and expired water vapour. This method, of course, has the advantage of convenience, but gives no direct evaluation of the physiological behaviour of the respiratory mucosa during anaesthesia. What is really going on in the lung with regard to humidity and temperature is a subject that has been poorly explored. Indeed research in this field has been severely limited by the lack of convenient instrumentation. It is, however, our belief that adding humidity to anaesthetic gas mixtures should be considered a premature achievement as long as a sound basic knowledge of respiratory hydrology in anaesthesia has not been completed.

Most hygrometers have been designed to test "outside" air. They are not applicable to the evaluation of heat and moisture variations induced in the respiratory tract during anaesthesia. In order to be convenient for this purpose, a hygrometer should be designed to analyse "inside" air, viz, the atmosphere confined in the anatomical dead space of the patient. After evaluating the existing methods, we designed a modified dew-point hygrometer endowed with characteristics which would overcome some of the limitations inherent in the existing moisture monitors. The object of this presentation is to summarize the thermodynamic principles involved in its conception and to describe its basic design.

-From the Department of Anaesthesia and Resuscitation, Hótel-Dieu de Québec, Québec, P.Q. 


\section{THEORY}

\section{Properties of Water Vapour}

The process by which liquid water is converted into vapour is called vaporization or evaporation. Molecules of water having sufficient kinetic energy to overcome the attractive forces tending to hold them within the body of liquid water are projected through the water surface. Since kinetic energy increases and surfaces tension decreases as temperature rises, the rate of evaporation increases with temperature.

In any gas mixture, each gas exerts a partial pressure independent of the other gases. The partial pressure exerted by water vapour will hereafter either be indicated by the abbreviation $\mathrm{P}_{\mathrm{H}_{2} \mathrm{O}}$ or called its vapour pressure. Practically speaking, the maximum amount of water vapour that can exist in any given space is a function of temperature, and is independent of the coexistence of other gases. When the maximum amount of water vapour for a given temperature is contained in a given space, the space is said to be saturated. The pressure exerted by the vapour in a saturated space is called the saturation vapour pressure, $\left(e_{10}\right)$, which is, by definition, the maximum vapour pressure possible at a given temperature.

The process by which vapour changes to the liquid state is called condensation. In a space in contact with a water surface, condensation and vaporization always go on simultaneously. If the space is not saturated, the rate of vaporization will exceed the rate of condensation, resulting in a net evaporation. If the space is saturated, the rates of vaporization and condensation balance, provided that the water and air temperature are the same.

Vaporization removes heat from the liquid being vaporized, while condensation adds heat. The latent. heat of vaporization is the amount of heat absorbed by a unit mass of the substance, without changes in temperature, while passing from the liquid to the vapour state. The change from vapour to the liquid state releases an equivalent amount of heat known as the latent heat of condensation. The heat of vaporization of water, $\left(\mathrm{H}_{\mathrm{v}}, \mathrm{cal} . / \mathrm{g}\right.$.) varies with temperature, but may be accurately determined up to $40^{\circ} \mathrm{C}$. by the equation $\mathrm{H}_{\mathrm{v}}=597.3-0.56 \mathrm{~T}$, where $\mathrm{T}$ is the temperature in degrees centigrade.

The relative humidity (R.H.) is the percentage ratio of the actual to the saturation vapour pressure and is therefore a ratio of the amount of moisture in a given space to the amount the space could contain if saturated. This is usually expressed by the formula

$$
\text { R.H. }=100\left(e / e_{v}\right) \text {, }
$$

where $e$ is the water vapour partial tension actually found in a space, and $e /{ }_{10}$ is the saturation vapour pressure of water at the same temperature.

\section{The Dew-point}

The dew-point principle is well known, and has undergone the test of years. The essentials of the dew-point theory were already set forth by LeRoy more than two centuries ago.4 We can define the dew-point $\left(\mathrm{T}_{d}\right)$ as the temperature at which a moist gas at a given temperature and pressure must be cooled in 
order to be saturated. This saturation is usually detected as a deposit of a very thin layer of mist on a cooled surface. The temperature is measured directly on the deposition surface. The evolution of this deposit is easily followed either visually or by optical devices, as it clouds a polished surface. True dew-point is the temperature at which a very faint trace of dew remains on the cool surface without increasing or decreasing in amount. In practice, using a dew-point hygrometer, the relative humidity is determined from the ratio of the vapour pressure at dew-point temperature to the saturation vapour pressure of water at sampling temperature. This ratio may be expressed in the following way:

$$
\text { R.H. }=e_{w}\left(\mathrm{~T}_{d}\right) / e_{v}\left(\mathrm{~T}_{s}\right),
$$

where $e_{w}\left(\mathrm{~T}_{d}\right)$ is saturated vapour pressure of water at the dew point, and $e_{w}\left(T_{s}\right)$ is saturated vapour pressure of water at sampling temperature.

Incorporating this principle of operation into a practical instrument requires the following parts: a suitable surface for the dew deposit; a temperature sensor and devices to control the surface temperature first towards cooling for dewpoint appearance, then towards heating for dew disappearance. In order to be used in confined areas, the instrument should include a convenient sampling system. These various components will now be considered in detail.

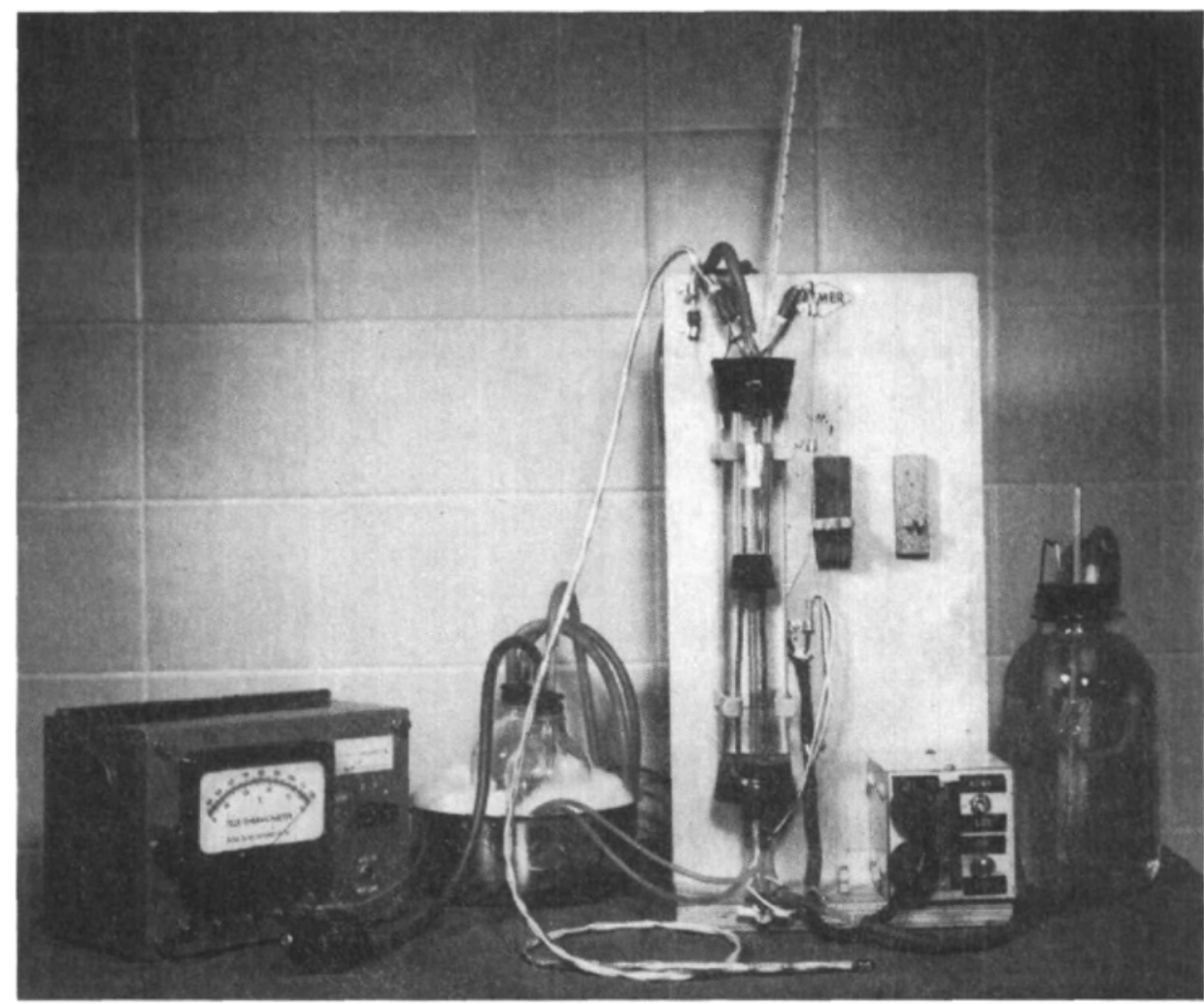

Ficure 1. The modified dew-point hygrometer. A photograph of the complete system. 


\section{Descrmption}

The complete apparatus is shown in Figure 1, whereas Figure 2 presents a diagrammatic illustration of its principal parts. It consists of two concentric chambers, vertically mounted on a convenient board. The innermost component is a glass tube with a capacity of 30 c.c. Inlet and outlet sampling ducts are

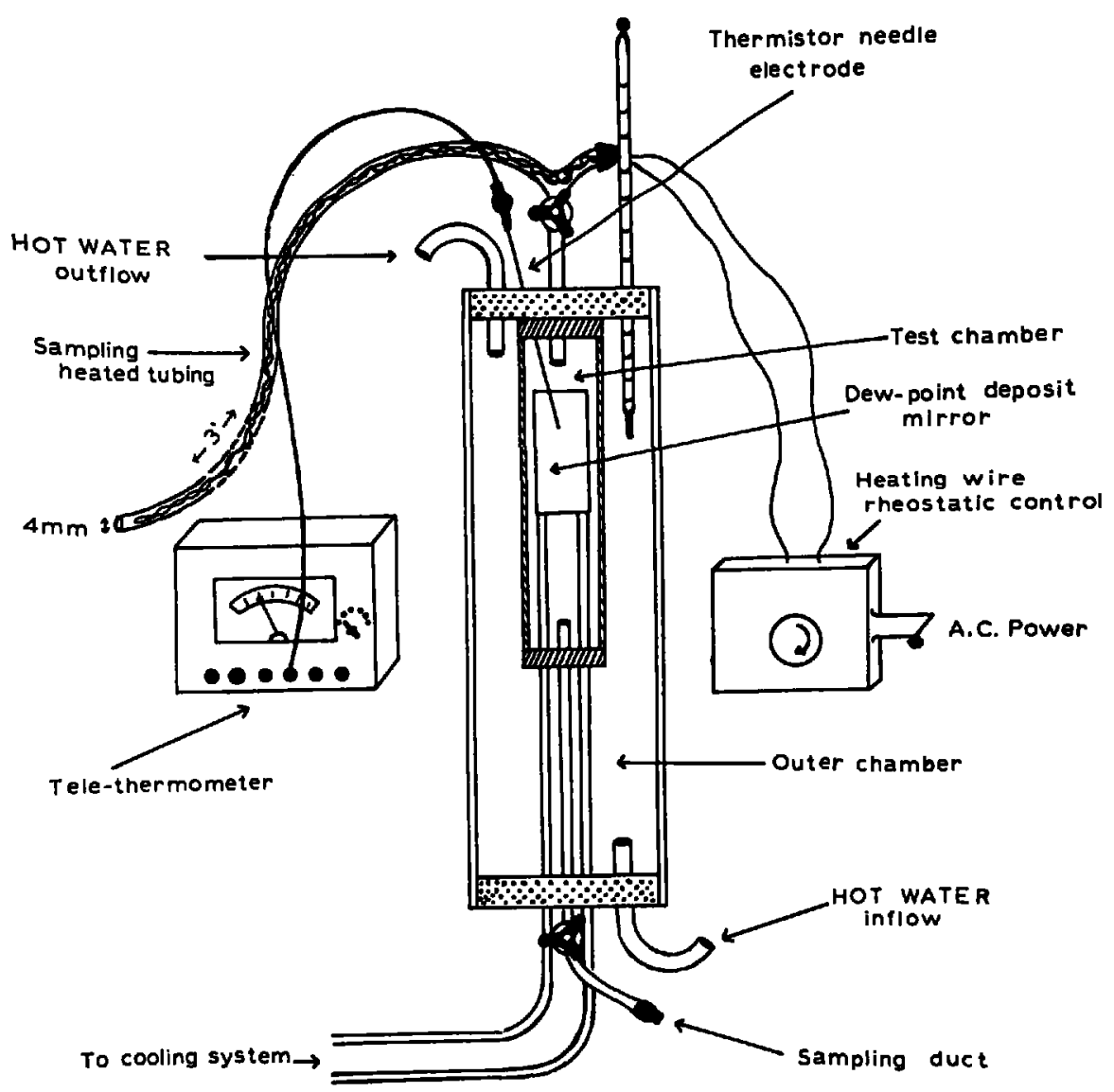

Ficure 2. A simplified sketch of the general assembly.

closed by stopcocks located at both ends of this tube. The dew-point mirror and its temperature sensor are found within the test chamber. The reflective surface for dew deposition is provided by a stainless steel plated copper mirror about $3.5 \mathrm{~cm}$. long and $1.5 \mathrm{~cm}$. wide. Soldered at the back of the mirror is a $2 \mathrm{~mm}$. wide copper coil connected to the cooling unit by insulated piping. Closely applied on the front surface of the mirror is a miniature needle thermistor of high accuracy $\left(0.25^{\circ} \mathrm{F}\right.$.) and very fast response (response time: 2.5 seconds). Indeed these two salient features of the thermistor set the basis for the over-all accuracy of the hygrometer. The calibration of the thermistor may be easily checked by comparison with the mercury laboratory thermometer located in the annular space between the two glass chambers. 
The outer glass jacket, filled with water, is intended to act as a thermal insulating device around the test chamber. Initial experiments with this type of dew-point detector disclosed the need to maintain the water temperature in this tube at $10^{\circ} \mathrm{C}$. higher than the temperature of the gas to be sampled: (1) to prevent dew precipitation on the glass surface of the inner tube; (2) to permit thorough sampling of the test chamber with a saturated gas without condensation; (3) as a means of heating the mirror to evaporate the dew; (4) to provide convection currents in the inner tube, which ventilate the gas sample on the mirror. The tap water used to perfuse the outer chamber appeared opaque due to a suspension of myriads of air bubbles. This situation was clarified by interposing a "debubbling bottle" on the heating perfusion system, as shown in Figure 1.

Most dew-point hygrometers use a continuously cooled mirror which is intermittently heated thereafter. We have successfully reversed the assembly, using a continuously heated mirror with intermittent cooling. The low-boilingtemperature acetone immersed in solid $\mathrm{CO}_{2}$ was found convenient as a cooling medium. This coolant was circulated under pressure from twin bottles, through the copper coil at the rear of the deposition mirror. The last component in the instrument is the sampling duct. Gases or air under test were carried into the test chamber through a 3 foot long, $4 \mathrm{~mm}$. wide polytetrafluoroethylene tubing. Most of the internal diameter of the tubing was occupied by insulated heating resistance wires, connected to a transitorized rheostatic control. The importance of this particular design of the gas inlet system is apparent if one remembers that the confined spaces from which samples are to be obtained during anaesthesia may well be the lower respiratory tract. A long tube, heated along its whole length at $38^{\circ} \mathrm{C}$., permits sampling of a gas saturated at $37^{\circ}$ without fear that water may be lost by condensation on its way to the test tube. Cramer ${ }^{5}$ found that a small segment of tubing measuring $\not$ in. could condense $3 \mathrm{mg}$. of moisture when the room temperature was $51^{\circ} \mathrm{F}$. When one considers that in the respiratory field we are dealing with amounts of water as small as $18 \mathrm{mg} . / 100$ c.c. of air, it is understandable why attention to this detail is important.

\section{Accuracy}

A number of different tests were carried out during the course of the development of this instrument, with a view to checking its performance. Calibration was performed repeatedly with samples of known humidity and temperature. These were obtained from a non-adiabatic saturator, of the bubbling type, as described by Bartlett. ${ }^{\circ}$ Calibrating gases at a moisture content below saturation were released by the addition of known volumes of dry gas to the saturated source. The accuracy of the readings is illustrated in Figure 3.

The instrument yields readings that are relatively coherent in a statistical sense, with a mean error of 2.41 per cent R.H. $(p<0.05)$. Admittedly, this hygrometer is not a high-precision device. Some highly sophisticated hygrometers have an accuracy of 0.5 per cent R.H. ${ }^{7}$ Our obvious sources of error originate at the visual detection of both the dew deposit and the thermistor response. This could be corrected by adding a photoelectric dew detector and a 


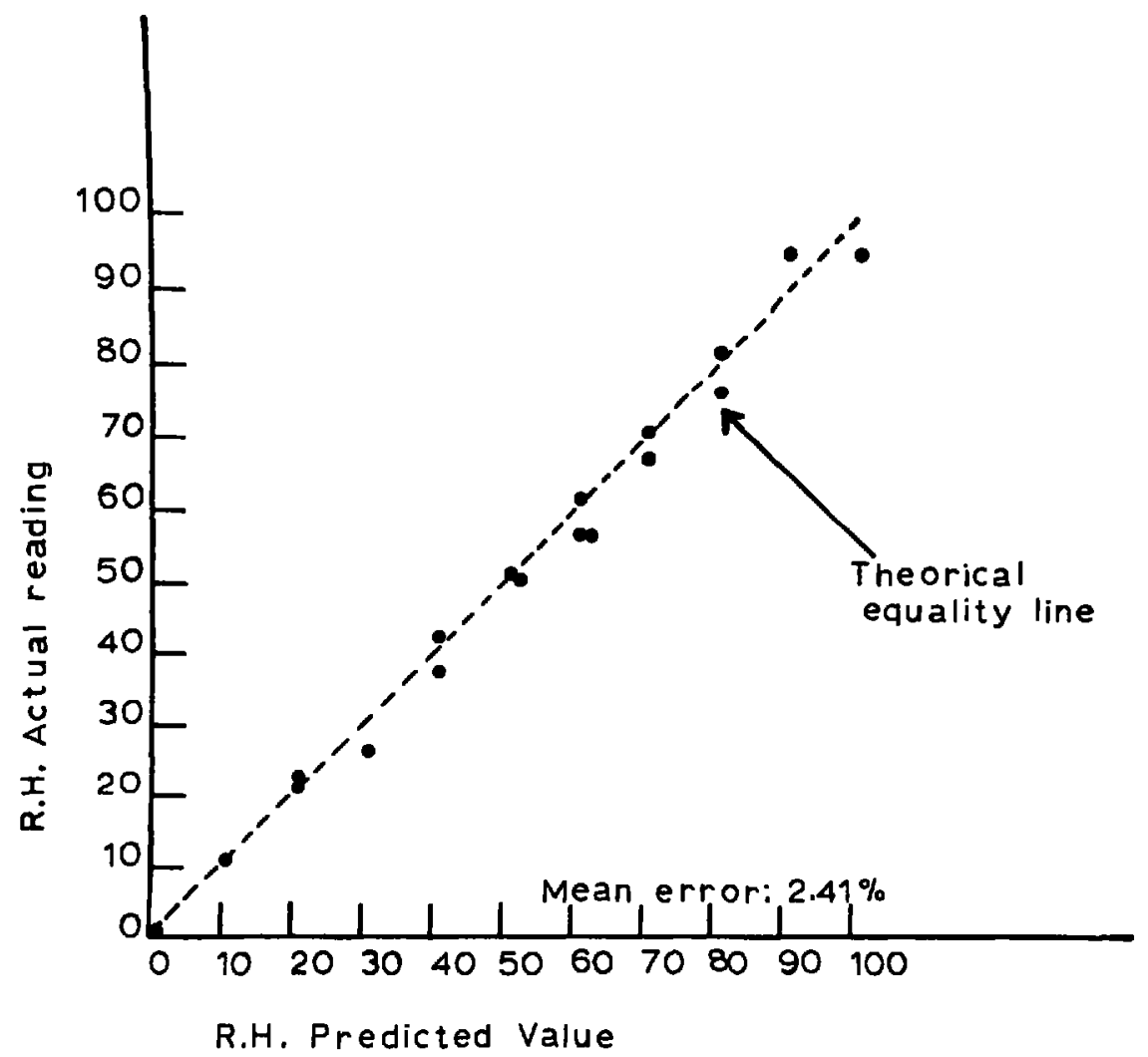

FIGUne 3. Representative calibration curve of the modified dew-point hygrometer.

precision electronic temperature amplifier with a suitable recorder. Unfortunately, these devices are not readily available. However, the degree of accuracy and reproductibility disclosed by the instrument during calibration procedures was found acceptable in practice and could be compared to advantage with some of the more conventional hygrometers actually used in hospitals (dry-andwet-bulb psychrometers, hair hygrometer, Regnault hygrometer).

\section{Operation and Applications}

Procedures before sampling, if we except calibration, are rapidly and easily completed. The test chamber and the sampling tube are thoroughly flushed with oxygen dehydrated by passage through a canister filled with anhydrous calcium chloride. The electronic control of the rheostatic heater is switched on and the temperature of the sampling duct conveniently adjusted. In the mean time, temperature of the outer water jacket is balanced by perfusion of warm water from the "debubbling bottle." The sampling tube is then intubated into the confined area to be analysed. The sample is driven through the test chamber by manipulating a syringe fastened to the air outlet duct. Usually, breath-by-breath aliquots of 30 c.c. of the gas under test are drawn through the system for ten 
consecutive respiratory cycles. Thus flushing the test chamber with a volume ten times its capacitance practically ensures an uncontaminated gas sample. Thereafter, with both cocks closed to the test chamber, determination of the dew-point can be made at leisure in the laboratory. The test chamber being hermetically closed, opportunity for further contamination is remote. In our experiments the whole procedure could well be performed in two or three minutes.

This apparatus has been used to study humidity in a wide variety of applications, such as soda-lime hygrometry and moisture patterns in the respiratory tract during anaesthesia. It will make further studies of humidity in anaesthesiology possible.

\section{Conclusion}

There is clearly a need for a device based on sound thermodynamic principles, which is capable of yielding information on the water vapour of gas mixtures circulated through anaesthetic systems and ventilated into the respiratory tract of patients during anaesthesia. The newly designed dew-point hygrometer reported affords an opportunity to test gases from confined areas, and has the advantages of stability and portability, acceptable accuracy, and simplicity of the whole assembly, since it can be easily built and calibrated.

There is one obvious disadvantage of the instrument. It is not explosion-proof, even though the electrical connections are insulated and the heating element secured with resistances.

Hydrology in anaesthesia is a poorly explored area. We hope that the humidity detector just described will contribute to the understanding of the "air conditioning" of anaesthetic mixtures.

\section{RÉSUMÉ}

La nécessité de mesurer l'humidité relative dans les voies respiratoires en cours d'anesthésie revêt de nos jours une importance croissante. Des publications récentes ont surtout fait état des efforts tentés pour incorporer des générateurs d'humidité dans les circuits anesthésiques. Cependant l'évaluation préalable du degré d'humidité déjà existant dans l'espace mort anatomique des patients soumis à l'anesthésie demeure un domaine pauvrement exploré. Il nous a semblé urgent de préciser ce degré d'humidité avant de songer à ajouter fortuitement de la vapeur d'eau aux gaz inspirés.

Comme la plupart des hygromètres actuellement disponibles ne satisfaisaient pas aux exigences de cette exploration, nous avons construit un appareil basé sur le principe du "point de rosée" et dont la caractéristique principale demeure de permettre un échantillonage représentatif de l'atmosphère contenu dans des endroits confinés et difficiles d'accès. Il nous a été fort utile, en cours d'investigation, de repasser les principes thermodynamiques sur lesquels le fonctionnement de cet instrument repose: vaporisation, condensation, humidités relative et absolue, point de rosée, thermométrie.

L'appareil, tel qu'illustré sur les Figures 1 à 3, comporte comme parties 
essentielles: (1) Deux chambres de verre dont l'une représente l'enceinte d'échantillonage; l'autre, externe par rapport à la première, fournit son isolation thermique grâce à un système de perfusion d'eau chaude. (2) Un miroir, fait d'une plaque de cuivre chromé, logé à l'intérieur du tube d'échantillonage. Sur sa face antérieure repose un thermistor de type aiguille, lui-même relié à un télé-thermomètre electronique. Sa face postérieure est parcourue par un serpentin réfrigérant perfusé par de l'acétone en contact avec de la glace carbonique. (3) Un tube de prélèvement chauffé par un fil électrique isolé relié à un contrôle rhéostatique.

Le fonctionnement de l'instrument est à la fois rapide et fidèle. A la suite des nombreuses épreuves de calibration auxquelles nous l'avons soumis, nous avons pu préciser la reproductibilité de ses lectures d'humidité relative qui se situe à 2.41 pour cent d'erreur moyenne. Cette marge d'erreur, attribuable à la détection visuelle du point de rosée, se compare avantageusement d celle des hygromètres conventionnels.

Cet appareil nous a permis d'entreprendre une évaluation du conditionnement hygroscopique des mélanges gazeux circulés dans les machines d'anesthésie et ventilés dans les voies respiratoires du patient. Les observations recueillies feront l'objet de publications ultérieures. Le comportement hygroscopique de la chaux sodée, l'évolution de la température et de l'humidité dans l'airway, la physiologie alvéolaire et l'humidité, l'influence de l'adjonction de saturateurs dans les circuits anesthésiques, voilà un champs d'investigation encore assez obscur où nous croyons que, grâce à cet hygromètre simple, stable et suffisamment précis, un peu de lumière peut être apporté.

\section{ACKNOWLEDGMENTS}

The authors wish to thank Dr. A. Sindon, F.R.C.P.(C), for his invaluable assistance in this investigation. They also acknowledge their debt to Mr. D. Blaney who contributed to the electronic design, to Mr. André Dufresne and Louise Bouchard, i.l., who prepared the figures.

\section{REFERENCES}

1. Wrnands, J. E. \& Wriglex, F. R. H. A Simple Method of Humidifying Anaesthetic Gases. Canad. Anaesth. Soc. J. 13: 403 (1966).

2. Sertery, F. E. Study of Changes in Temperature and Water Vapor Content of Respired Air in Nasal Cavity. Heating, Piping, and Air Conditioning. 12: 377 (1940).

3. Burce, G. E. Study of Water and Heat Loss from Respiratory Tract of Man. Arch. Int. Med. 76: 308 ( 1945).

4. Symons, G. J. A Contribution to the History of Hygrometers. Quart. J. Met. Soc. 7: 161 (1881).

5. Cramer, I. I. Heat and Moisture Exchange of Respiratory Mucous Membrane. Ann. Otol. Rhin. \& Laryng. 66: 327 (1957).

6. BartLeTt, E. P. The Concentration of Water Vapor in Compressed Hydrogen, Nitrogen and a Mixture of These Gases in the Presence of Condensed Water. J. Am. Chem. Soc. 49: 65 (1927).

7. Ruskus, R. E. Humidity and Moisture. Vol. I, Principles and Methods of Measuring Humidity in Gases. 1st ed. New York: Reinhold (1965). 